Benha Veterinary Medical Journal 37 (2019) 112-117

Benha Veterinary Medical Journal
Official Journal Issued by
Faculty of
Veterinary Medicine $\quad$ Journal homepage: https://bvmj.journals.ekb.eg/

Original Paper

\title{
Isolation and identification of Cronobacter species from some animal products
}

\author{
Ashraf Abd El Tawab ${ }^{1}$, Amira Mohamed ${ }^{1}$, Ahmed Ammar ${ }^{2}$, Mohamed Mohamed ${ }^{3}$ \\ ${ }^{I}$ Department of Bacteriology, Immunology and Mycology, Faculty of Veterinary Medicine, Benha University, Egypt \\ ${ }^{2}$ Department of Microbiology, Faculty of Veterinary Medicine, Zagazig University, Egypt \\ ${ }^{3}$ Department of Zoonosis, Faculty of Veterinary Medicine, Zagazig University, Egypt
}

\begin{tabular}{|c|c|}
\hline ARTICLE INFO & ABSTRACT \\
\hline $\begin{array}{l}\text { Received 06/10/2019 } \\
\text { Accepted 01/12/2019 } \\
\text { Available On-Line } \\
\text { 12/05/2020 }\end{array}$ & $\begin{array}{l}\text { This work was carried out to study the bacteriological importance of Cronobacter sakazakiias } \\
\text { a potential foodborne emerging pathogen involved in severe illness and deaths in humans, } \\
\text { especially neonates due to consumption of contaminated infant powdered infant formula (PIF) } \\
\text { (PIF milk and food). A total of } 100 \text { samples [PIF milk ( } \mathrm{n}=55) \text {, PIF food ( } \mathrm{n}=15 \text { ), milk powder } \\
\text { ( } \mathrm{n}=15 \text { ) and milk powder products }(\mathrm{n}=15 \text { ) were collected and subjected to bacteriological } \\
\text { examination for the presence of Cronobacter. Six samples out of } 100 \text { examined ( } 6 \% \text { ) were } \\
\text { found positive for Cronobacter spp. The isolation rates were } 4 \% \text { in PIF milk and } 1 \% \text { in PIF } \\
\text { food. The identity of the isolated organism was confirmed as Cronobacter spp. by subjecting } \\
\text { the bacteriologically positive samples to PCR technique using } 16 \mathrm{~S} \text { rRNA species specific } \\
\text { primers. Cronobacter specific } 16 \mathrm{~S} \text { rRNA was detected respectively in } 3 / 5 \text { and } 1 / 5 \text { of } \\
\text { bacteriologically positive PIF milk and PIF food examined. All positive } 16 \mathrm{~S} \text { rRNA (n=4) were } \\
\text { examined for the presence of } C \text {. sakazakii. C. sakazakiiwere confirmed in an isolate from } 3 \\
\text { isolates of PIF milk and one of PIF food. The outer membrane protein A (ompA) gene was } \\
\text { detected in } 2 \text { identified } C \text {. sakazakii isolates, while gene encoding for zinc-metaloprotease (zpx) } \\
\text { was only identified in } 3 \text { C. sakazakii isolates. These results lead to the conclusion that examined } \\
\text { milk products could be a potential source of C. Sakazakii, so the retailed powdered milk could } \\
\text { have public health significance. Further studies are needed to study control strategies of } C \text {. } \\
\text { sakazakii. }\end{array}$ \\
\hline
\end{tabular}

\section{INTRODUCTION}

Cronobacter spp. are emerging foodborne opportunistic pathogens that can infect neonates and infants resulting in necrotizing enterocolitis, bacteremia, and meningitis, with a 40-80\% mortality rate (Holy and Forsythe, 2014; Li et al., 2016). Cronobacter sakazakii has been previously known as Enterobacter sakazakii. It is Gram-negative bacteria, motile peritrichous, rod-shaped, nonspore forming sakazakii bacteria belonging to the family Enterobacteriacea. In addition, these bacteria are typically facultative anaerobic, oxidase-negative, catalase positive; it also produces a yellow pigment (Iversen et al., 2007). A high mortality rate particularly in infants has been documented due to consumption of contaminated PIF (Lampel and Chen, 2009). The genus Cronobacter has been divided into seven species: Cronobacter sakazakii, Cronobacter malonaticus, Cronobacter turicensis, Cronobacter muytjensii, Cronobacter dublinensis, Cronobacter universalis, and Cronobacter condimenti (Joseph et al., 2012 $2^{\mathrm{a}, \mathrm{b}}$; Yao et al., 2012). Infant milk powder was implicated as the main source of Cronobacter resulting in 50-80\% of infections (van Acker et al., 2001; Ye et al., 2010).

However, various food and environmental samples have also been documented as sources of infection (Iversen and Forsythe, 2004;Kandhaiet al. 2004 \& 2010;Friedemann, 2007). Severe meningitis, meningo-encephalitis, necrotizing enterocolitis, and sepsis caused by $C$. sakazakii have been reported in neonates consuming infant powdered milk (Caubilla-Barron et al., 2007). Moreover, surviving patients were reported to suffer severe neurological signs including hydrocephalus and developmental delay (Lai, 2001). Infection in elderly immune-compromised individuals consuming contaminated milk powder have also been reported (Lai, 2001; van Acker et al., 2001). Virulence associated genes in Cronobacter spp. have a role in the potential of these bacteria to produce pathogenic effect in infected persons. The outer membrane protein A associated gene (ompA) and the gene encoding for zinc-metaloprotease $(z p x)$ are both considered important virulence factors (Mohan Nair and Venkitanarayanan, 2006). The main objective of this study is to investigate the isolation and identification of Cronobacter sakazakii in different samples including powdered infant formula (milk and food), milk powder, and some milk powder products. Identification of virulence associated genes of the isolates were carried out. In addition of antibiotic sensitivity of cronobacter isolates.

\footnotetext{
* Corresponding author: Prof. Ashraf Abd El Tawab Department of Bacteriology, Immunology and Mycology, Faculty of Veterinary Medicine, Benha University, Egypt
} 


\section{MATERIAL AND METHODS}

\subsection{Sampling}

One hundred samples of PIF milk ( $\mathrm{N}=55)$, PIF food $(\mathrm{N}=15)$, milk powder $(\mathrm{N}=15)$ and some milk powder products $(\mathrm{N}=15)$ at different localities in El Sharkia Governorate, Egypt during the period of April 2016 to February 2017.The collected samples were aseptically transported as soon as possible to the laboratory of Veterinary Hospital, Faculty of Veterinary Medicine, Zagazig University, for bacteriological examination.

\subsection{Isolation and identification of Cronobacter species} Pre-enrichment of the samples was performed in buffered peptone water at $37 \mathrm{C}$ for $24 \mathrm{~h}$ (ISO 2006). A portion $(0.1 \mathrm{~mL}$ ) of the culture was then transferred to $10 \mathrm{~mL}$ of Cronobacter screening broth (CSB 38948, Sigma) and incubated at 42 C for $24 \mathrm{~h}$, and then examined for changing of color to yellow (Iversen et al., 2008). A loopful from the enriched CSB culture was streaked directly onto Cronobacter species isolation chromogenic agar (CSIA; Sigma, 14703; Hichrome CISA) and incubated at $44^{\circ} \mathrm{C}$ for $24 \mathrm{~h}$.

\subsection{Identification of Cronobacter species}

\subsubsection{Microscopic examination}

Films were prepared from the pure cultures of the isolated organism. Each film was stained with Gram's staining technique and examined microscopically to verify the presence of characteristic features of the organism and to confirm the specificity of the colonies (Cruickshank etal., 1975).

\subsubsection{Biochemical identification of bacterial isolates}

Biochemical identification of Cronobacter spp. was carried out using catalase, oxidase, indole, and urea hydrolysis and citrate utilization tests as previously described by Cruickshank etal. (1975).

2.3.2.1 Catalase test: A loopful from three days old culture was mixed with a drop of hydrogen peroxide $3 \%\left(\mathrm{H}_{2} \mathrm{O}_{2}\right)$ on a clean sterile slide. Appearance of gas bubbles indicates catalase production.

2.3.2.2 Oxidase test: A loopful from the suspected colonies was rubbed on the surface of oxidase discs (Hi media, DD018). The appearance of intense deep purple color within few seconds indicates oxidase production.

2.3.2.3 Indole test: Kovac's reagent $(0.5 \mathrm{ml})$ was added to 24 $\mathrm{h}$ peptone water culture and incubated at $37^{\circ} \mathrm{C}$. The development of rosy color ring indicates the presence of indole.

2.3.2.4 Urea hydrolysis test: The isolated microorganism was streaked onto the surface of Christensen's medium (Hi media, M112) and incubated at $37^{\circ} \mathrm{C}$ for $24-48 \mathrm{~h}$. The negative tubes were re-incubated and re-examined daily up to 7 days. A purple pink color indicates urea hydrolysis.

2.3.2.5 Citrate utilization test Simmon's citrate agar (Hi media, M099) slopes were streaked with a loopful of the suspected isolates and incubated at $37^{\circ} \mathrm{C}$ for up to seven days. The development of blue color indicates citrate utilization.

\subsection{Molecular identification of Cronobacter species} The DNA from biochemically suspected Cronobacter isolates was extracted using QIAamp DNA Mini Kit (Cat. no. 51304, Qiagen) according to the manufacturer's instructions. Amplification of $16 \mathrm{~S}$ rRNA specific for Cronobacter spp. was carried out using conventional PCR (Hassan et al., 2007). The virulence associated genes ompA (Mohan NairandVenkitanarayanan,2006) and zpx (Kotharyet $a l ., 2007)$ were also identified by PCR. A positive control of C. sakazakii was kindly provided by the Biotechnology Unit, Reference laboratory for Veterinary Quality Control on Poultry Production, Animal Health Research Institute, Dokki, Giza, Egypt. For further confirmation of $C$. sakazakii isolates identified by $16 \mathrm{~S}$ rRNA PCR from buffalo fecal samples, sequencing of the amplified products was carried out. QIAquick Gel Extraction Kits (Qiagen, S. A. Courtaboeuf, France) were used for amplicon extraction from gel according to the manufacturer's guidelines. The purified products were sequenced with Big dye Terminator V3.1 Cycle Sequencing Kits (PerkinElmer, Foster City, CA) as described by the manufacturer. DNASTAR software (Lasergene ver. 7.2, DNASTAR, Madison, WI) was used to analyze two sequences that were then submitted to the GenBank, which provided the two accession numbers of KY210879 and KY210880. Identity of the two isolates with other C. sakazakii isolates on the GenBank was determined.

\subsection{Antibiotic susceptibility testing}

The PCR confirmed 4 Cronobacter isolates (C. sakazakii) were subjected to antibiotic susceptibility testing against eight commonly used antibiotics. The standard Kirby-Bauer disk diffusion method according to the National Committee for Clinical Laboratory Standards was used to determine the antimicrobial sensitivity profiles of Cronobacter isolates (NCCLS, 2013). These antibiotics with the respective disk concentrations were Streptomycin (5 mg), Gentamycin (10 $\mathrm{mg})$, Meropenem (10 mg), Rifampicin (10 mg), Cefotaxime (30 $\mathrm{mg})$, Lincomycin $(10 \mathrm{mg})$, Cefoperazone $(30 \mathrm{mg})$ and Ciprocin $(5 \mathrm{mg})$. The antibiotic disks were placed on the inoculated plates, and then the plates were incubated at $35^{\circ} \mathrm{C}$ for $18-20 \mathrm{~h}$. The plates were examined for the presence of zones of inhibition of bacterial growth around the antibiotic discs which indicate the susceptibility of the isolated strains to these antibiotics. The zones of inhibition were then measured with a caliber and recorded (CLSI, 2014).

\section{RESULTS}

Table1PCR results of 5 Cronobacter isolates recovered from PIF milk and PIF food.

\begin{tabular}{lccc}
\hline Sample & 16S rRNA & ompA & $z p \boldsymbol{x}$ \\
\hline PIF1 (milk) & - & Not done & Not done \\
PIF2 (food) & + & - & + \\
PIF3 (milk) & + & + & - \\
PIF4 (milk) & + & + & - \\
PIF5 (milk) & + & - & - \\
\hline
\end{tabular}


Table 2 Isolation of Cronobacter spp. isolated from different sources (PIF milk PIF food, powdered milk and powdered milk products) by bacteriological and PCR.

\begin{tabular}{|c|c|c|c|c|c|c|c|c|}
\hline \multirow[t]{3}{*}{ Sample types } & \multirow[t]{3}{*}{ Number examined } & \multicolumn{3}{|c|}{ Cronobacter spp. isolates based on } & \multicolumn{2}{|c|}{ C. sakazakii (ompA -) } & C. sakazakii (zpx-) & \multirow[t]{2}{*}{$+\mathrm{ve}(\%)$} \\
\hline & & \multirow[t]{2}{*}{ Growth +ve (\%)a } & \multicolumn{2}{|c|}{ 16S rRNA PCR } & & \multirow[b]{2}{*}{ No. $(\%) \mathrm{c}$} & \multirow[b]{2}{*}{ No. $(\%)$ a } & \\
\hline & & & No. $(\%) \mathrm{a}$ & No. $(\%) \mathrm{b}$ & No. $(\%) \mathrm{a}$ & & & No.(\%)c \\
\hline $\begin{array}{l}\text { PIF milk } \\
\end{array}$ & 55 & $4(7 \%)$ & $3(5 \%)$ & $3(6 \%)$ & $2(3.6 \%)$ & $2(50 \%)$ & $1(18 \%)$ & $1(25 \%)$ \\
\hline PIF food & 15 & $1(6 \%)$ & $1(6 \%)$ & $1(2 \%)$ & $1(6 \%)$ & $1(25 \%)$ & 0 & 0 \\
\hline MP & 15 & $1(6 \%)$ & 0 & 0 & 0 & 0 & 0 & 0 \\
\hline MPP & 15 & 0 & 0 & 0 & 0 & 0 & 0 & 0 \\
\hline
\end{tabular}

MP: Milk powder. MPP: Milk powder product. (a) The percentage in relation to the total examined samples (b) The percentage in relation to the bacteriologically +veCronobacter spp. (c)The percentage in relation to the $16 \mathrm{~S}$ rRNA +veCronobacter spp.

Table 3 Antibiotics susceptibility of Cronobacter sakazakii isolates recovered from different sources.

\begin{tabular}{llcccc}
\hline Antibiotic class & Antibiotic & \multicolumn{3}{c}{ Cronobacter isolates (n=4) } & ARI index= Y/nX \\
& & S(ratio) & $\mathrm{I}($ ratio) & $\mathrm{R}($ ratio) & \\
\hline Quinolones/Fluoroquinolones & Ciprocin (CIP) & $4 / 4$ & 0 & 0 & 0.00 \\
Cephalosporins (Third generation) & Cefoperazone (CFP) & $2 / 4$ & $1 / 4$ & $1 / 4$ & 0.03 \\
& Cefotaxime (CTX) & $3 / 4$ & 0 & $1 / 4$ & 0.03 \\
Beta lactam & Meropenem(MEM) & $3 / 4$ & 0 & $1 / 4$ & 0.03 \\
Aminoglycosides & Gentamicin (CN10) & $3 / 4$ & 0 & $1 / 4$ & 0.03 \\
& Streptomycin (S) & 0 & $1 / 4$ & $3 / 4$ & 0.09 \\
Rifamycin & Rifampicin (RF) & 0 & $1 / 4$ & $3 / 4$ & 0.09 \\
Lincosamides & Lincomycin (L2) & $1 / 4$ & $1 / 4$ & $2 / 4$ & 0.06
\end{tabular}

S: Sensitive. I: Intermediate. R: Resistant. ARI: Antibiotic Resistance Index. $\mathrm{Y}=$ the number of resistant isolates to certain antibiotics. $\mathrm{N}=$ the total number of tested isolates. $\mathrm{X}=$ the total number of tested antibiotics.

\begin{tabular}{|c|c|c|c|c|c|}
\hline Patterns & Isolate code & Isolate source & Resistance profile & $\mathrm{N}$ & MARindex (a/b) \\
\hline I & PIF1 & Powdered infant milk & $\mathrm{R}, \mathrm{L}, \mathrm{S}$ & 3 & 0.38 \\
\hline II & PIF2 & Powdered infant milk & $\mathrm{R}, \mathrm{S}$ & 2 & 0.25 \\
\hline III & PIF3 & Powdered infant milk & $\mathrm{R}, \mathrm{L}, \mathrm{S}$ & 3 & 0.38 \\
\hline IV & PIF4 & Powdered infant food & $\mathrm{M}, \mathrm{F}, \mathrm{G}, \mathrm{C}, \mathrm{R}, \mathrm{L}, \mathrm{S}$ & 7 & 0.88 \\
\hline
\end{tabular}

Average MAR $=0.47 . \mathrm{F}$ (Cefoperazone), C (Cefotaxime), I (Ciprofloxacin), G (Gentamicin), R (Rifampicin), $\mathrm{S}$ (Streptomycin), M (meropenem),L (lincomycin).N = Number of antibiotics showing resistant. a: the number of antibiotics to which the isolates are resistant. b: the total number of tested antibiotics (8).

\begin{tabular}{|c|c|c|c|c|c|c|c|c|c|c|c|c|}
\hline \multirow{2}{*}{$\begin{array}{l}\text { Sample } \\
\text { number }\end{array}$} & \multirow[t]{2}{*}{ Date of isolation } & \multirow[t]{2}{*}{ Locality } & \multirow[t]{2}{*}{ Source } & \multicolumn{5}{|c|}{ Biochemical identification } & \multicolumn{3}{|c|}{ PCR } & \multirow[b]{2}{*}{ Antibiotic sensitivity } \\
\hline & & & & Oxidase & Catalase & Citrate & Urea & Indole & 16SrRNA & OmpA & zpx & \\
\hline 1 & $6 / 5 / 2016$ & Zagazig, Sharkia & PIF milk & $-\mathrm{ve}$ & $+\mathrm{ve}$ & $+\mathrm{ve}$ & $-\mathrm{ve}$ & $-\mathrm{ve}$ & $-\mathrm{ve}$ & $-\mathrm{ve}$ & $-\mathrm{ve}$ & Not done \\
\hline 2 & $10 / 5 / 2016$ & Fquos, Sharkia & PIF milk & $-v e$ & $+\mathrm{ve}$ & $+\mathrm{ve}$ & $-\mathrm{ve}$ & $-v e$ & $+\mathrm{ve}$ & $-\mathrm{ve}$ & $+\mathrm{ve}$ & $\mathrm{R}, \mathrm{L}, \mathrm{S}$ \\
\hline 3 & $10 / 5 / 2016$ & $\mathrm{Al}$ hussainia, Sharkia & PIF milk & $-\mathrm{ve}$ & $+\mathrm{ve}$ & $+\mathrm{ve}$ & $-\mathrm{ve}$ & $-\mathrm{ve}$ & $+\mathrm{ve}$ & $+\mathrm{ve}$ & $-\mathrm{ve}$ & $\mathrm{R}, \mathrm{S}$ \\
\hline 4 & $1 / 5 / 2016$ & Zagazig, Sharkia & PIF milk & - ve & $+\mathrm{ve}$ & $+\mathrm{ve}$ & $-\mathrm{ve}$ & $-v e$ & $+\mathrm{ve}$ & $+\mathrm{ve}$ & $-\mathrm{ve}$ & $\mathrm{R}, \mathrm{L}, \mathrm{S}$ \\
\hline 5 & $17 / 5 / 2016$ & Abokabir, Sharkia & PIF food & - ve & $+\mathrm{ve}$ & $+\mathrm{ve}$ & $-\mathrm{ve}$ & $-v e$ & $+\mathrm{ve}$ & $-\mathrm{ve}$ & $-\mathrm{ve}$ & $\mathrm{M}, \mathrm{F}, \mathrm{G}, \mathrm{C}, \mathrm{R}, \mathrm{L}, \mathrm{S}$ \\
\hline 6 & $17 / 5 / 2016$ & Zagazig, Sharkia & PIF milk & $-v e$ & $+\mathrm{ve}$ & $+\mathrm{ve}$ & $+\mathrm{ve}$ & $-v e$ & Not done & Not done & Not done & Not done \\
\hline
\end{tabular}

F (Cefoperazone), C (Cefotaxime), I (Ciprofloxacin), G (Gentamicin), R (Rifampicin), S (Streptomycin), M (Meropenem),L (Linco mycin).

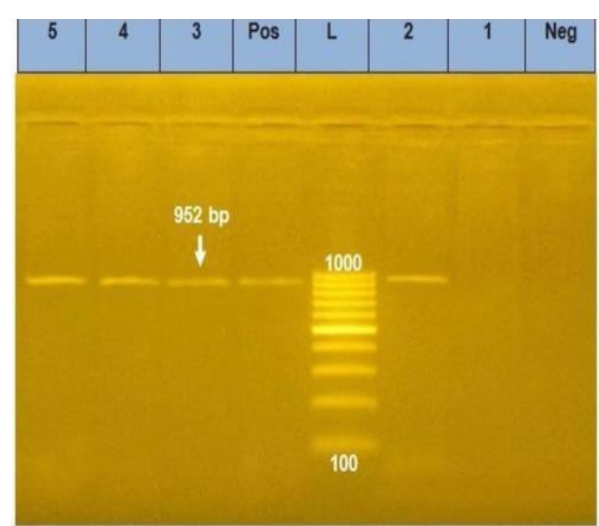

Figure 1 Amplification of 168 rRNA gene for the molecular identification of cronobactersakazakii isolates recovered from different sources with an amplicon size 952 bp . L: 100 bp ladder, Pos: C. sakazakii positive control, Neg: Negative control. $(2,3,4,5)$ positive samples, (1) negative sample.

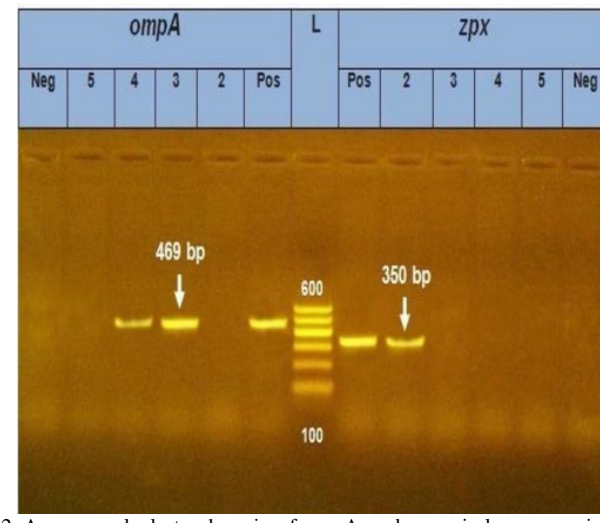

Figure 2 Agarose gel electrophoresis of $о т p \mathrm{~A}$ and $z p x$ virulence associated genes amplification in Cronobacter isolates from different sources with amplicon size of $469 \mathrm{bp}$ for ompA and $350 \mathrm{bp}$ for zpx gene. L: $100 \mathrm{bp} \mathrm{ladder,} \mathrm{Pos:} \mathrm{C.} \mathrm{sakazakiipositive} \mathrm{control,}$ Neg: Negative control, ( 3,4 left): Positive samples for ompA. (2 right): positive sample for zpx gene. 


\section{DISCUSSION}

Isolation and identification of Cronobacter spp. In the current study, showed that out of 100 examined samples, 6 (6\%) were bacteriologically suspected as Cronobacter species. However, only $4(4 \%)$ were contaminated with $C$. sakazakii confirmed by PCR amplification of 16S rRNA sequence specific for Cronobacter species. This result is supported by Saleh (2016) who found that $2(2 \%)$ of the examined PIF samples were positive for Cronobacter spp. and only $1(1 \%)$ was identified as $C$. sakazakii, this agreement may be due to single source of contamination. Nearly similar results of Cronobacter isolation were previously reported in PIF samples, for instance, $1.5 \%$ in Iraq (Al-Timimi, 2007), 1.9\% in Nigeria (Rashidat et al., 2013), 2.4\% in different countries (Iversen and Forsythe, 2004), 2.5\% in Turkey (Heperkan et al., 2017), $3 \%$ in France (Proudyet al., 2008) and 3.1\% in Bangladesh (Hoque et al., 2010). However, higher isolation rates of Cronobacter spp. ranging from $6.6 \%$ to $25 \%$ were also documented, $6.6 \%$ in Japan (Oonaka et al., 2010), 8.7\% in Netherlands (Kandhai et al., 2010), 13\% in Ivory Coast (Yao et al., 2012), 13.3\% in Egypt (El-Sharoudet al., 2009), 18\% in Iraq (Jaber et al., 2015), 24\% in Egypt (El-Gamal et al., 2013), 24\% in Nigeria (Moses David et al., 2013) and 25\% in Jordan (Shaker et al., 2007). In the present study, four of the milk powder samples were positive for the presence of Cronobacter spp. The presence of Cronobacter spp. in milk powder samples is unusual due to normal pasteurization of liquid milk before manufacturing of milk powder products and the pasteurization process is considered an effective step for elimination of Cronobacter contamination (Iversen and Forsythe, 2004; Shaker et al., 2007). Molecular amplification of ompA gene revealed that 2 out of $4(50 \%)$ Cronobacter isolates harbored ompA associated gene (isolates from PIF), while, only one isolates of PIF were positive for $z p x$ associated gene.

In accordance, Cronobacter isolates from PIF were positive for ompA gene (Cai et al., 2013; Fei et al., 2015). Sequencing of 16S rRNA was carried out on C. sakazakii isolates which revealed that 4 Cronobacter spp were positive 16S rRNA and one negative sample (non-C. sakazakii). The $16 \mathrm{~S}$ rRNA sequencing is a powerful technique for rapid and specific identification of different Cronobacter species (Lehner et al., 2006; Hassan et al., 2007; Jaradatet al., 2009). in the current study, Cronobacter isolates were highly sensitive to Ciprocin (100\%) followed by Gentamycin $(75 \%)$, cefotaxime $(75 \%)$ and meropenem $(75 \%)$, while they were less sensitive to cefoperazone (50\%) and poorly sensitive to lincomycin (25\%). Meanwhile, the isolates were resistant to Rifampicin (75\%) and Streptomycin (75\%). The high sensitivity of Cronobacter isolates to ciprofloxacin is in accordance with other reported studies (Stock and Wiedemann, 2002; AlTimimi, 2007; Kim et al., 2008a;
Hoque et al., 2010; Oonaka et al., 2010; Hochel et al., 2012; Jaber et al., 2015; Oloninefa et al., 2015). The susceptibility of Cronobacter isolates to cephalosporins (ceftriaxone, cefotaxime and cefoperazone in the current study is in agreement with those previously documented (Muytjens and van der Ros-van de Repe, 1986; Al-Timimi, 2007; Terragnoet al., 2009; Aigbekaen and Oshoma, 2010; Hoque et al., 2010; Oonaka et al., 2010; Hochel et al., 2012; Oloninefa et al., 2015). The calculated antibiotic resistant index (ARI) in our work ranged from zero to 0.09 this result reveals the diversity of anti-biogram profile of isolated $C$. sakazakii strains. The MAR index ranged from 0.25 to 0.88 , with the highest MAR index (0.88) found in C. sakazakii strain recovered from powdered infant formula food. The lowest MAR index (0.25) was found in the isolates from PIF milk. C. sakazakii isolate number 4 was multi-resistant strain showing resistance to 7 antibiotics, isolates number 1and 3 were resistant to 3 antibiotics, and isolate number 2 was resistant to only 2 antibiotics. The isolates were retrieved from different localities in Sharkia governorate and various date of isolation from the same PIF source; this may be due to various source of contamination. Nevertheless, the isolate number 3 was resistant to 2 antibiotics in different sources (PIF, milk and food) this may refer to single sources of contamination. Isolate number 6 was morphologically suspected $C$. sakazakii in plate on selective media but biochemically was negative.

\section{CONCULOSION}

From the obtained results it could concluded that, powdered infant formula is considered as the most important reservoirs for Cronobacter spp. especially for C. sakazakii. Reconstitution and consumption of powdered infant formula is regarded as a risk for infection in infants. Quinolones and Cephalosporin's is the drug of choice for treatment of Cronobacter infected cases in Sharkiagovernorate.

\section{REFERENCES}

1. Aigbekaen, B.O., Oshoma, C.E. (2010): Isolation of Enterobacter sakazakiifrom powderedfoodslocally consumed in Nigeria. Pakistan Journal of Nutrition, 9: 659-663.

2. Al-Timimi, B.J. (2007): Antimicrobial resistance of bacteria isolated from powdered infant formulas (PIF). Medical Journal of Babylon, 4: 251-262

3. Cai, X.Q., Yu, H.Q., Ruan, Z.X., Yang, L.L., Bai, J.S., Qiu, D.Y., Jian, Z.H., Xiao, Y.Q., Yang, J.Y., Le, T.H., Zhu, X.Q. (2013): Rapid detection and simultaneous genotyping of Cronobacter spp. (formerly Enterobactersakazakii) in powdered infant formula using real-time PCR and high resolution melting (HRM) analysis. PloS One, 8: e67082.

4. Caubilla-Barron, J., Hurrell, E., Townsend, S., Cheetham, P., Loc-Carrillo, C., Fayet, O., Prère, M.F., Forsythe, S.J. (2007): Genotypic and phenotypic analysis of Enterobactersakazakii strains from an outbreak resulting in fatalities in a neonatal intensive care unit in France. Journal of Clinical Microbiology, 45: 3979-3985.

5. CLSI (2014): Clinical and Laboratory Standards Institute: Performance Standards for Antimicrobial Susceptibility 
Testing. 24th informational supplement. CLSI M100-S24, Wayne, PA.

6. El-Gamal, M.S., El Dairouty, R.K., Okda, A.Y., Salah, S.H., El-Shamy, S.M. (2013): Incidence and interrelation of Cronobactersakazakii and other foodborne bacteria in some milk products and infant formula milks in Cairo and Giza Area. World Applied Sciences Journal, 26: 1129-1141.

7. El-Sharoud, W.M., O'Brien, S., Negredo, C., Iversen, C., Fanning, S., Healy, B. (2009): Characterization of Cronobacter recovered from dried milk and related products. BMC Microbiology, 9: 24.

8. Fei, P., Man, C., Lou, B., Forsythe, S.J., Chai, Y., Li, R., Niu, J., Jiang, Y. (2015): Genotyping and source tracking of Cronobacter sakazakii and C. malonaticus Isolates from powdered infant formula and an infant formula production factory in China. Appliedand Environmental Microbiology, 81: 5430-5439.

9. Friedman, M. (2007): Enterobactersakazakii in food and beverages (other than infant formula and milk powder). International Journal of food Microbiology, 116:1-10

10. Hassan, A.A., Akineden, O., Kress, C., Estuningsih, S., Schneider, E., Usleber, E. (2007): Characterization of the gene encoding the 16S rRNA of Enterobactersakazakii and development of a species-specific PCR method. International Journal of Food Microbiology, 116: 214-220.

11. Heperkan, D., Dalkilic-Kaya, G., Juneja, V.K. (2017): Cronobacter sakazakii in baby foods and baby food ingredients of dairy origin and microbiological profile of positive samples. LWT - Food Science and Technology, 75: 402-407.

12. Hochel, I., Ruzickova, H., Krasny, L., Demnerova, K. (2012): Occurrence of Cronobacterspp. in retail foods. Journal of Applied Microbiology, 112: 1257-1265.

13. Holy, O., and Forsythe, S. (2014). Cronobacterspp. as emerging causes of health care associated infection. J. Hosp. Infect. 86, 169-177.

14. Hoque A., Ahmed, T., Shahidullah, M., Hossain, A., Mannan, A., Noor, K., Nahar, K., Ilias, M., Ahmed, D. (2010): Isolation and molecular identification of Cronobacterspp. from powdered infant formula (PIF) in Bangladesh. International Journal of Food Microbiology, 142: 375-378.

15. ISO (2006): International Organization for Standardization: Milk and milk products, Detection of Enterobactersakazakii. ISO/TS 22964.

16. Iversen, C., Forsythe, S. (2004): Isolation of Enterobactersakazakii and other Enterobacteriaceae from powdered infant formula milk and related products. Food Microbiology, 21: 771-777.

17. Iversen, C., Lehner, A., Mullane, N., Marugg, J., Fanning, S., Stephan, R., Joosten, H. (2007): Identification of "Cronobacter" spp. (Enterobacter sakazakii). J Clin Microbiol, 45: 3814-3816.

18. Iversen, C., Mullane, N., McCardell, B., Tall, B.D., Lehner, A., Fanning, S., Stephan, R., Joosten, H. (2008): Cronobacter gen. nov., a new genus to accommodate the biogroups of Enterobacter sakazakii, International Journal of Systematic and Evolutionary Microbiology, 58: 1442-1447.

19. Jaber, A.S., Al-Badry, B.J., Hussein, M.H. (2015): Diagnosis of Enterobactersakazakii from samples of infant milk, stool and Haboubi hospital environment in DhiQar province and study the sensitivity for some antibiotics. World Journal of Pharmaceutical Research, 4: 2524-2535.

20. Jaradat, Z.W., Ababneh, Q.O., Saadoun, I.M., Samara, N.A., Rashdan, A.M. (2009): Isolation of Cronobacterspp. (formerly Enterobactersakazakii) from infant food, herbs and environmental samples and the subsequent identification and confirmation of the isolates using biochemical, chromogenic assays, PCR and 16S rRNA sequencing. BMC Microbiology, 9: 225-235.

21. Joseph, S., Cetinkaya, E., Drahovska, H., Levican, A., Figueras, M. J., and Forsythe, S. J. (2012a). Cronobacter condimentispnov., isolated from spiced meat, and Cronobacter universalisspnov., a species designation for Cronobactersp genomospecies, recovered from a leg infection, water and food ingredients. Int. J. Syst. Evol. Microbiol. 62, 1277-128//3

22. Kandhai, M.C., Heuvelink, A.E., Reij, M.W., Beumer, R.R., Dijk, R., van Tilburg, J.J.H.C., van Schothorst, M., Gorris,L.G.M. (2010): A study into the occurrence of Cronobacterspp. in The Netherlands between 2001 and 2005. Food Control, 21(8): 1127-1136.

23. Kandhai, M.C., Reij, M.W., Gorris, L.G., Guillaume-Gentil, O., van Schothorst, M. (2004): Occurrence of Enterobactersakazakii in food production environments and households. Lancet (London, England), 363: 39-40.

24. Kim, J.B., Cho, S.-H., Park, Y.B., Lee, J.B., Kim, J.C., Lee, B.K., Lee, H.K., Chae, H.S. (2008a): Surveillance of Stool Samples for the Presence of Enterobactersakazakii among Korean People. Yonsei Medical Journal, 49: 1017-1022.

25. Kothary MH, McCardell BA, Frazar CD, Deer D, Tall BD. (2007). Characterization of the zinc-containing metalloprotease encoded by $z p x$ and development of a speciesspecific detection method for Enterobactersakazakii. Appl Environ Microbiol., 73:4142-4151.

26. Lai, K.K. (2001): Enterobactersakazakii infections among neonates, infants, children, and adults. Case reports and a review of the literature. Medicine, 80: 113-122.

27. Lampel, K.A., Chen, Y. (2009): Method for the isolation and detection of Enterobactersakazakii (Cronobacter) from powdered infant formula. InternationalJournal of Food Microbiology, 136: 179-184.

28. Lehner, A., Nitzsche, S., Breeuwer, P., Diep, B., Thelen, K., Stephan, R. (2006): Comparison of two chromogenic media and evaluation of two molecular based identification systems for Enterobactersakazakii detection. BMC Microbiology, 6 (15): 1-8

29. Li, Y., Chen, Q., Zhao, J., Jiang, H., Lu, F., Bie, X., Lu, Z (2016): Isolation, identification and antimicrobial resistance of Cronobacterspp. isolated from various foods in China. Food Control, 37: 109-114.

30. Mohan Nair, M. K., and Venkitanarayanan, K. S. (2006). Cloning and sequencing of the ompA gene of Enterobacter sakazakii and development of an ompA targeted PCR for rapid detection of Enterobacter sakazakii in infant formula. Appl. Environ. Microbiol. 72:25-39.

31. Moses David, O., Christopher Falegan, R., OA, O. (2013): Pattern of breastfeeding and occurrence of Cronobactersakazakii in infant formula sold in Ekiti State, Nigeria. Shiraz E-Med Journal, 14: 21-34.

32. Muytjens, H.L., van der Ros-van de Repe, J. (1986) Comparative in vitro susceptibilities of eight Enterobacterspecies, with special reference toEnterobactersakazakii. Antimicrobial Agents and Chemotherapy, 29: 367-370

33. NCCLS (2013). Performance standards for antimicrobial susceptibility Testing. Twenty-Third Informational Supplement. CLSI document M100S23. (ISBN 1-56238-8657 [Print]; ISBN 1-56238-866-5 [Electronic]).

34. Oloninefa, S.D., Daniyan, S.Y., Abalaka, M.E. (2015): Antibiotics susceptibility profile and rate of killing of Cronobactersakazakii isolated from used, retailed infant formulas and opened-vended powdered milk by standard antibiotics. Journal of Medicine and Applied Biosciences, 2: 71-78.

35. Oonaka, K., Furuhata, K., Hara, M., Fukuyama, M. (2010): Powder infant formula milk contaminated with Enterobactersakazakii. Japanese Journal of Infectious Diseases, 63: 103-107.

36. Proudy, I., Bougle, D., Leclercq, R., Vergnaud, M. (2008): Tracing of Enterobactersakazakii isolates in infant milk formula processing by BOX-PCR genotyping. Journal of Applied Microbiology, 105: 550-558. 
37. Rashidat, E.A., Olugbo, A.O., Ifeanyi, S.S., Adetoun, F.W., Adedayo, O.E., Moses, B. (2013): Isolation and PCR detection of Cronobactersakazakiifrom powdered infant formulae retailed in Nigeria. American Journal of Food and Nutrition, 3: $182-187$

38. Saleh. K, (2016): Molecular Characterization of Cronobactersakazakii in Egypt, Survival and Thermo resistance at Different Temperatures: A Potential Public Health Risk.Master Thesis (Zoonoses), Fac. Vet. Med., Zagazig University, EGYPT.

39. Shaker, R., Osaili, T., Al-Omary, W., Jaradat, Z., Al-Zuby, M. (2007): Isolation of Enterobactersakazakiiand other Enterobactersp. from food and food production environments. Food Control, 18: 1241-1245.

40. Stock, I., Wiedemann, B. (2002): Natural antibiotic susceptibility of Enterobactercancerogenus, Enterobactergergoviae and Enterobactersakazakii strains. Clinical microbiology and infection: the official publication of the European Society of Clinical Microbiology and Infectious Diseases, 8: 564-578.

41. Terragno, R., Salve, A., Pichel, M., Epszteyn, S., Brengi, S., Binsztein, N. (2009): Characterization and subtyping of
Cronobacterspp. from imported powdered infant formulae in Argentina. International Journal of Food Microbiology, 136: 193-197.

42. Van Acker, J., de Smet, F., Muyldermans, G., Bougatef, A Naessens, A., Lauwers, S. (2001): Outbreak of necrotizing enterocolitis associated with Enterobactersakazakii in powdered milk formula. Journal of Clinical Microbiology, 39: 293-297.

43. Yao, K., Zinzendorf, N.Y., Bohoua, G., Kouassi, K.A., Koua, A., Kouadio, L.K., Kouamé, P., Loukou, G.Y. (2012): Occurrence of Enterobactersakazakii (Cronobacter) and other Enterobacteriaceae in commercial powdered infant formula in Abidjan, Ivory Coast. Food and Nutrition Sciences, 3: 822826.

44. Ye, Y., Wu, Q., Xu, X., Yang, X., Dong, X., and Zhang, J. (2010). The phenotypic and genotypic characterization of Enterobactersakazakii strains from infant formula milk. J. Dairy Sci. 93, 2315-2320. doi: 10.3168/jds. 20092662 repetitive sequence polymerase chain reaction (rep-PCR) reveals different discriminatory capabilities. Microbial Ecology, 58: 843-855. 